\title{
BDTORIAL
}

\section{A SOBEP para os \\ enfermeiros pediatras}

\author{
Ivone Evangelista Cabral ${ }^{1}$ \\ Conceição Vieira da Silva ${ }^{2}$
}

Vários enfermeiros pediatras de diversas regiões do País, reunidos em 09 de outubro de 1996, durante o 48 Congresso Brasileiro de Enfermagem da Associação Brasileira de Enfermagem, realizado na cidade de São Paulo, fundaram a Sociedade Brasileira de Enfermeiros Pediatras (SOBEP). Ela tem como propósito congregar enfermeiros que atuam assistindo/cuidando, ensinando e pesquisando na área da criança e adolescente, tendo dentre outras, as seguintes finalidades: a) promover o desenvolvimento técnico, científico e cultural da enfermagem pediátrica; b) promover a união e articulação com as demais entidades representativas da enfermagem e de áreas afins, na defesa dos justos interesses dos associados e da criança/adolescente; c) realizar exames para Titulo de Especialista em Enfermeiro Pediatra, em suas subespecialidades.

Com apenas cinco anos de existência, a Sociedade vem trabalhando articulada com a Associação Brasileira de Enfermagem (ABEn) e outras organizações de enfermagem e da área de saúde da criança para oferecer aos seus associados uma entidade legalmente constituída e legitimamente reconhecida pelo grupo de especialistas.

É com muita alegria que a diretoria atual da SOBEP apresenta o volume de lançamento da Revista, que corresponde ao primeiro periódico especializado de enfermagem pediátrica brasileira. Trata-se não só, de um espaço de divulgação do conhecimento de saúde da criança, estendendo-se do período do nascimento à adolescência; mas também para publicação de idéias, opiniões, dúvidas, questionamentos e reflexões.

Neste número, o leitor defrontar-se-á com conferências, relatos de experiência e artigos de revisão e pesquisa, os quais serão muito úteis para a ampliação de sua cultura profissional e atualização de conhecimentos.

1 - Coordenadora da Comissão de Publicação, Divulgação e Comunicação Social da Sociedade Brasileira de Enfermeiros Pediatras (SOBEP). Enfermeira pediatra. Doutora em enfermagem.

2 - Presidente da SOBEP. Enfermeira pediatra. Doutora em enfermagem. 
Além da Revista, a SOBEP está preparando para os seus associados, um novo projeto gráfico de seu Boletim semestral, a criação da homepage e a implantação desta Revista na versão eletrônica. No dia 18 de julho de 2001, já acontecerá no Rio de Janeiro a primeira prova de titulação de especialistas em enfermagem pediátrica com área de concentração em terapia intensiva, nesta edição você encontrará maior detalhamento.

Este é apenas o nosso começo. Tal como uma criança em formação, o futuro da Sociedade dependerá do que nós faremos por ela!

Contamos com seu apoio para o crescimento e desenvolvimento de nossa SOBEP.

Uma boa leitura! 